\title{
Fish oil as effective supplement preventing inflammatory and histopathological alterations in adjuvant-induced arthritis in rats
}

\author{
Óleo de Peixe como suplemento eficaz na prevenção de alterações inflamatórias e histopatológicas \\ na artrite induzida por adjuvante em ratos \\ El aceite de pescado como complement eficaz en la prevención de cambios inflamatorios e \\ histopatológicos en la artritis inducida por adyuvantes en ratas
}

Received: 03/18/2021 | Reviewed: 03/26/2021 | Accept: 03/29/2021 | Published: 04/08/2021

Camila Fernanda Estevão-Silva ORCID: https://orcid.org/0000-0002-7230-9862 State University of Maringá, Brazil E-mail: camila.fet@gmail.com

Alessandra Mileni Versuti Ritter ORCID: https://orcid.org/0000-0002-4434-4791 University of Campinas, Brazil E-mail: ale_mileni@hotmail.com

Franciele Queiroz Ames ORCID: https://orcid.org/0000-0001-7653-9430 State University of Maringá, Brazil E-mail: francieleames@gmail.com Bruno Ambrósio da Rocha

ORCID: https://orcid.org/0000-0002-5847-7667 State University of Maringá, Brazil

E-mail: brunoambrosiorocha@ fai.com.br Jurandir Fernando Comar

ORCID: https://orcid.org/0000-0002-9518-7589 State University of Maringá, Brazil

E-mail: jurandircomar@yahoo.com.br

Edirlene Sara Wisniewski-Rebecca ORCID: https://orcid.org/0000-0003-4872-0915 State University of Maringá, Brazil E-mail: esara_wis@yahoo.com.br

Silvana Martins Caparroz-Assef ORCID: https://orcid.org/0000-0001-9326-132X State University of Maringá, Brazil

E-mail: smcassef@gmail.com

Roberto Kenji Nakamura Cuman ORCID: https://orcid.org/0000-0002-4906-887X State University of Maringá, Brazil E-mail: rkncuman@uem.br

Luzmarina Hernandes

ORCID: https://orcid.org/0000-0003-4284-4394 State University of Maringá, Brazil E-mail: luzhernandes@gmail.com

Ciomar Aparecida Bersani-Amado ORCID: https://orcid.org/0000-0002-0247-2090 State University of Maringá, Brazil E-mail: cabamado@uem.br

\begin{abstract}
In this study was investigated the effect of treatment with a fish oil preparation (FOP) on inflammatory and histopathological parameters in a rat model of adjuvant-induced arthritis (AIA). Paw edema, the severity of secondary lesions, the number of synovial leukocytes, and serum nitric oxide and cytokines concentrations were evaluated. Histological changes in cartilage and bone of the femorotibial articulation in the paws were analyzed by hematoxylin/eosin and sirius red-hematoxylin staining. Oral treatment with the FOP $(75,150$, and $300 \mathrm{mg} / \mathrm{kg})$ that was initiated on the day of arthritis induction (day zero) and maintained for 21 days inhibited inflammatory signals and prevented morphological changes in cartilage and bone of the femorotibial articulation of the paws. These effects could be at least partially attributable to inhibitory and modulatory actions of the FOP on the production and release of nitric oxide and cytokines that participate in the pathophysiology of AIA.
\end{abstract}


Keywords: Fish oil; Freund's complete adjuvant; Antiinflammatory effect; Cytokines.

\section{Resumo}

Nesse estudo foi investigado o efeito do tratamento com uma preparação de óleo de peixe (POP) sobre parâmetros inflamatórios e histopatológicos na artrite induzida por adjuvante em ratos (AIA). O edema de pata, a gravidade das lesões secundárias, o número de leucócitos sinoviais e a concentração sérica de óxido nítrico e de citocinas foram avaliados. Alterações histológicas nas cartilagens e nos ossos das articulações fêmoro-tibiais das patas foram analisadas pelas técnicas de coloração hematoxilina/eosina e sirius red-hematoxilina. O tratamento oral com a POP $(75,150$, e $300 \mathrm{mg} / \mathrm{kg}$ ) iniciado no dia da indução da artrite (dia zero) e mantido por 21 dias inibiu os sinais inflamatórios e preveniu as alterações morfológicas na cartilagem e no osso das articulações. Esses efeitos podem ser parcialmente atribuídos à ação modulatória e inibitória da POP sobre a produção/liberação de óxido nítrico e citocinas que participam da fisiopatologia da AIA.

Palavras-chave: Óleo de peixe; Adjuvante completo de Freund; Efeito anti-inflamatório; Citocinas.

\section{Resumen}

En este estudio se investigó el efecto del tratamiento con una preparación de aceite de pescado (PAP) sobre los parámetros inflamatorios y histopatológicos en un modelo de artritis inducida por adyuvante en ratas (AIA). Se evaluó el edema de la pata, la gravedad de las lesiones secundarias, el número de leucocitos sinoviales y las concentraciones séricas de óxido nítrico y citocinas. Los cambios histológicos en el cartílago y el hueso de la articulación femorotibial en las patas se analizaron mediante tinción con hematoxilina / eosina y rojo de sirio-hematoxilina. El tratamiento oral con PAP $(75,150$ y $300 \mathrm{mg} / \mathrm{kg}$ ) que se inició el día de la inducción de la artritis (día zero) y se mantuvo durante 21 días inhibió las señales inflamatorios y previno cambios morfológicos en el cartílago y hueso de la articulación femorotibial de las patas. Estos efectos podrían atribuirse, al menos en parte, a las acciones inhibidoras y moduladoras de la PAP sobre la producción y liberación de óxido nítrico y citocinas que participan en la fisiopatología de la AIA.

Palabras clave: Aceite de pescado; Adyuvante completo de Freund; Efecto antiinflamatório; Citocinas.

\section{Introduction}

Fish oil (FO) is a rich source of n-3 long-chain (also known as omega-3) polyunsaturated fatty acids (PUFAs), especially eicosapentaenoic acid (EPA; 20:5n-3) and docosahexaenoic acid (DHA; 22:6n-3), and has many health benefits. Supplementation with omega-3 PUFAs has been recommended as an adjuvant therapy for rheumatoid arthritis and cancer and the prevention of ischemic heart disease (Calder, 2014;. Calder; 2010; He et al., 2020; Mattos \& Andrade, 2006; Simopoulos, 2002).

Its supplementation has also been recommended for treatments with some drugs that cause severe adverse events or do not have good pharmacological efficacy in chronic diseases (He et al., 2020; Mori et al., 2000).

The mechanisms of these effects appear to be related to modulation of the signaling and expression of genes, changes in the composition of the cell membrane, changes in the population of immune cells, and the production of eicosanoid (He et al., 2020; Mori et al., 2000; Watson et al., 2018).

In adjuvant-induced arthritis (AIA), a plantar injection of Freund's complete adjuvant (CFA) is an intense and persistent inflammatory stimulus that significantly increases the number of inflammatory cells and the production and release of inflammatory mediators in the affected joint. These events contribute to joint cartilage damage, bone resorption, and other systemic changes in arthritic animals, similar to rheumatoid arthritis in humans (LaBranche et al., 2012). Pharmacological treatment to inhibit the migration and number of leukocytes that are recruited to the joint can reduce local and systemic damage and is an interesting therapeutic intervention.

In our previous study, we observed an inhibitory effect of FO preparation (FOP) on the number of leukocytes that were recruited to the joint cavity and rolling and adhered leukocytes in a rat model of adjuvant-induced arthritis (Estevão-Silva et al., 2016), but no study has proving the effectiveness of daily supplementation with FO in severe systemic joint and bone changes that occur in AIA.

The present study investigated the effects of treatment with a FOP on inflammatory and histopathological parameters in arthritic rats. 


\section{Methodology}

\subsection{Animals}

In this study, in vivo experiments were performed on Holtzmann rats, weighing 210-220 g, randomly divided into standard polypropylene cages, in an environment with a controlled temperature $\left(22^{\circ} \mathrm{C} \pm 2^{\circ} \mathrm{C}\right)$ under a $12 \mathrm{~h} / 12 \mathrm{~h}$ light/dark cycle with standard chow and water available ad libitum. Rats were acclimated for 1 week before initiation of experiment. The number of animals used was the minimum necessary to obtain statistical significance and were used only in a single experimental group.The experimental protocol chosen for this study were previously standardized in our laboratory (EstevãoSilva et al. 2016; Ritter et al., 2017) and was approved by the Animal Ethics and Experimentation Committee of the State University of Maringá (CEAE/UEM 045).

\subsection{Drugs}

The FO consisted of $250 \mathrm{mg}$ DHA and $50 \mathrm{mg}$ EPA and was purchased commercially from Naturalis laboratory (São Paulo, Brazil). Olive oil was obtained from Andorinha (Algés, Portugal). Naproxen was purchased from the Medicinal pharmacy (Maringá, Paraná, Brazil). Ketamine hydrochloride was obtained from Agner União (São Paulo, Brazil). Xylazine hydrochloride was obtained from Rompun (Bayer, São Paulo, Brazil). Nujol was obtained from Schering-Plough (São Paulo, Brazil).

\subsection{Fish oil preparation and treatment groups}

The contents of the FO capsules were diluted in olive oil to obtain the FOP in amounts of 37.5, 75, 150, and 300 $\mathrm{mg} / \mathrm{kg}$ by considering the amount of DHA in each preparation. These FOPs were based on Estevão-Silva et al. (2016). The rats were randomly assigned to nine treatment groups $(n=7)$ : Group I (N- normal rats), Group II (AIA- untreated arthritics rats), Groups III-VI (arthritics rats treated with the FOP at 37.5, 75, 150, and $300 \mathrm{mg} / \mathrm{kg}$ ), Group VII (arthritics rats treated with pure FO at $300 \mathrm{mg} / \mathrm{kg}$ ), Group VIII (arthritics rats treated with olive oil [i.e., the diluent (Oo) that was used for the FOP] in an amount that was equivalent to treatment with the FOP), and Group IX (arthritics rats treated with $3 \mathrm{mg} / \mathrm{kg}$ of the reference antiinflammatory drug naproxen $[\mathrm{Npx}])$. The animals were treated with a single daily dose orally by gavage, which was started on the day of arthritis induction (day zero) and continued until day 21 after AIA induction.

\subsection{Arthritis induction and assessment}

To induce arthritis, the animals were first anesthetized with a solution of ketamine $(50 \mathrm{mg} / \mathrm{kg})$ and xylazine (10 $\mathrm{mg} / \mathrm{kg}$ ), and then $0.1 \mathrm{ml}$ of a CFA suspension (killed and dried Mycobacterium tuberculosis suspended in mineral oil [Nujol $\left.{ }^{\circledR}\right]$ ) at a concentration of $0.5 \%(\mathrm{w} / \mathrm{v})$ was injected subcutaneously in the left hindpaw. The induction day was set as experimental day 0 . The inflammatory response that was induced by CFA was evaluated in the hindpaws in arthritic rats on days 1, 3, 6, 9, 13, 17, and 21. The volume of the injected paw and non-injected contralateral paw was evaluated with a plethysmograph (Ugo Basile). The results are expressed as an increase in paw volume $(\mu 1)$ relative to its initial volume. The evaluation of secondary lesions (i.e., the presence of nodules in the ears and tail and edema in the forepaws) was performed from day 1 to day 21 after arthritis induction and was maintained until the end of the experiment (day 21). To evaluate these lesions, a numerical scale as proposed by Rosenthale (1970) was used, in which points are assigned for each of the following events: +1 (appearance of nodules in the tail), +1 or +2 (appearance of nodules in one or both ears), and +1 or +2 (swelling of one or both forelimbs). The severity of lesions was graded from 0 (zero) to 5 , with zero indicating the absence of lesions. 


\subsection{Determination of serum concentrations of nitric oxide and cytokines}

On day 21 after arthritis induction, the different animal groups were anesthetized to collect blood from the inferior vena cava. Samples were centrifuged at $700 \times g$ at $4^{\circ} \mathrm{C}$ for $15 \mathrm{~min}$ and then stored at $-70^{\circ} \mathrm{C}$ for further biochemical analysis.

The concentration of nitric oxide was determined using the Griess colorimetric method. This method indirectly quantifies nitric oxide by measuring the concentration of nitrite in the sample. Griess' solution (1\% sulfanilamide in $5 \%$ phosphoric acid and $0.1 \% \mathrm{~N}$-1-naphthyl ethylenediamine dihydrochloride in water) was added to each sample, which was read at $500 \mathrm{~nm}$ after $10 \mathrm{~min}$ to determine the nitrite concentration. The results were calculated based on a standard curve and are expressed as $\mu \mathrm{mol} / \mathrm{ml}$.

The plasma concentration of cytokines, tumor necrosis factor (TNF), interleukin (IL-1, IL-2, IL-6, IL-10), and granulocyte-macrophage colony stimulating factor (GM-CSF) were determined using a flow cytometer (MAGPIX Luminex, Austin, TX, USA) according to the manufacturer's instructions.

\subsection{Histological analysis of femorotibial articulation}

Normal, untreated arthritic (control) rats and arthritic rats that were treated with $300 \mathrm{mg} / \mathrm{kg} \mathrm{FOP,} 300 \mathrm{mg} / \mathrm{kg}$ FO, 3 $\mathrm{mg} / \mathrm{kg} \mathrm{Npx}$, or Oo were anesthetized and euthanized with ketamine $(500 \mathrm{mg} / \mathrm{kg})$ and xylazine $(100 \mathrm{mg} / \mathrm{kg})$ on day 21 . The right and left femorotibial articulations were collected and processed for further histological analysis. The samples were immersed in 10\% formalin for $48 \mathrm{~h}$ and then decalcified in $10 \%$ ethylenediaminetetraacetic acid (pH 7.4) for 21 days. The articulations were then dehydrated in different concentrations of alcohol solutions and embedded in paraffin. Semi-serial 6$\mu \mathrm{m}$-thick slices were stained with hematoxylin/eosin or sirius red-hematoxylin. Slides that were stained with HE were used both (1) to evaluate the intensity of the inflammatory response in the synovial membrane (right and left) and histopathological changes in articular cartilage (right and left) and (2) to analyze the morphometry of the right and left synovial membrane. Both evaluations were performed using an Olympus BX41 optical microscope (Tokyo, Japan).

The intensity of the inflammatory response in the synovial membrane in each group of rats was assessed using a score that ranged from 0 (zero) to 4 points (Ritter et al., 2017). This score was based on the number of inflammatory cells in the synovial membrane and their distribution in tissue, with zero indicating the absence of inflammatory infiltrate in the tissue and 4 indicating very intense inflammatory infiltrate, with the synovial membrane replete with inflammatory cells. The degree of structural alterations of articular cartilage (right and left) was assessed by a score that varied from 0 (zero) to 5 points according to severity ${ }^{11}$. This score was based on the cellular type and organization in the cartilage and shape and integrity of the surface of the articular membrane (Ritter et al., 2017), with zero indicating no change and 5 indicating a change in the number of chondrocytes, irregularities in the surface of the joint membrane, and pannus invasion into articular cartilage.

The morphometric analysis of the synovial membrane was performed by random measurements of the thickness of the right (three measurements) and left (three measurements) synovial membrane in each histological section. The measurements were taken in three histological sections per animal, for a total of 45 measurements per group. The thickness of the right and left articular cartilage was also determined. Five random measurements were taken for each histological section, for a total of 75 measurements per group. These analyses were performed using an optical microscope (Olympus BX41, Olympus, Tokyo, Japan) with $\mathrm{x} 4$ (synovial membrane) and $\mathrm{x} 10$ (cartilage) objectives The results are expressed as micrometers $(\mu \mathrm{m})$.

Sirius red-hematoxylin-stained sections were used to determine the area of the organic matrix on subcondral bone that underlies the femorotibial articulation in each group. The images were captured under polarized light using a Nikon Eclipse 80I optical microscope coupled to a high-resolution Nikon Ds-FilC camera (Minato-ku, Tokyo, Japan) with a 20× objective lens and analyzed using ImagePro Plus 4.5 image analysis software (Media Cybernetics, Silver Spring, MD, USA). Three random images were taken per histological section of each region, for a total of 180 images per group (right tibia [45], left tibia 
[45], right femur [45], and left femur [45]). The results are expressed as the area occupied by the organic matrix (left and right) in $\mu \mathrm{m}^{2}$.

\subsection{Statistical analysis}

The results are expressed as the mean \pm standard error of the mean (SEM). Significant differences among means were identified using Tukey's test. Values of $p<0.05$ were considered statistically significant. The statistical analyses were performed using GraphPad Prism 5.0 software (San Diego, CA, USA).

\section{Results}

\subsection{Treatment with FOP inhibited arthritic paw edema in rats}

Twenty-four hours after arthritis induction, we observed a significant increase in the volume of the injected paw in AIA control rats, with a progressive increase in edema until day 21. The volume of the contralateral paw (non-injected right hindpaw) progressively increased from day 10 to the end of the experimental period (day 21). Treatment with 75, 150, and 300 $\mathrm{mg} / \mathrm{kg}$ FOP and $300 \mathrm{mg} / \mathrm{kg}$ FO reduced edema in the injected paw (Figure 1A) and non-injected contralateral paw (Figure 1B) on days 13, 17 and 21. Naproxen ( $3 \mathrm{mg} / \mathrm{kg}$ ) reduced edema in the injected paw on days 3, 6, 9, 13, 17, and 21 and contralateral non-injected paw on days 13, 17, and 21 compared with the AIA control group. Treatment with $37.5 \mathrm{mg} / \mathrm{kg}$ FOP and olive oil (Oo) did not reduce edema in the injected paws or non-injected contralateral paws compared with the AIA group.

\subsection{Treatment with the FOP delayed the appearance and reduced the severity of secondary lesions in arthritic rats}

The severity of secondary lesions is shown in Table 1 . Treatment with 75, 150, and $300 \mathrm{mg} / \mathrm{kg} \mathrm{FOP,} 300 \mathrm{mg} / \mathrm{kg} \mathrm{FO}$, and $3 \mathrm{mg} / \mathrm{kg}$ Npx delayed the appearance of lesions, which were also milder compared with the AIA group. Treatment with $37.5 \mathrm{mg} / \mathrm{kg}$ FOP and olive oil (Oo) did not alter the severity of secondary lesions.

Table 1. Effect of fish oil preparation (FOP), pure fish oil (FO), olive oil (Oo), and naproxen (Npx) on secondary lesion scores after the induction of adjuvant-induced arthritis (AIA).

\begin{tabular}{ccccccc}
\hline Groups & \multicolumn{5}{c}{ Days after AIA induction } \\
\hline & 11 & 13 & 15 & 17 & 19 & 21 \\
\hline AIA & $3(1-3)$ & $5(2-5)$ & $5(4-5)$ & $5(5-5)$ & $5(5-5)$ & $5(5-5)$ \\
\hline Oo & $2(1-3)$ & $4(2-4)$ & $5(3-5)$ & $5(5-5)$ & $5(5-5)$ & $5(5-5)$ \\
\hline Npx & $1(0-1)^{*}$ & $2(1-3)^{*}$ & $4(3-5)^{*}$ & $5(5-5)$ & $5(5-5)$ & $5(5-5)$ \\
\hline FOP $_{37,5}$ & $2(1-3)$ & $5(4-5)$ & $5(4-5)$ & $5(5-5)$ & $5(5-5)$ & $5(5-5)$ \\
\hline FOP $_{75}$ & $1(0-2)^{*}$ & $2(1-4)^{*}$ & $4(4-5)$ & $5(4-5)$ & $5(4-5)$ & $5(4-5)$ \\
\hline FOP $_{150}$ & $1(0-2)^{*}$ & $3(1-4)^{*}$ & $4(3-5)^{*}$ & $5(4-5)$ & $5(4-5)$ & $5(4-5)$ \\
\hline FOP & & & & \\
300 & $1(0-2)^{*}$ & $3(2-4)^{*}$ & $4(3-5)^{*}$ & $5(4-5)$ & $5(4-5)$ & $5(4-5)$ \\
\hline FO & $0(0-2)^{*}$ & $3(2-3)^{*}$ & $4(3-5)^{*}$ & $5(4-5)$ & $5(4-5)$ & $5(4-5)$ \\
\hline
\end{tabular}

The evaluation of secondary lesions was done by assigning points to each of the following events: appearance of nodules in the tail $(+1)$, appearance of nodules in one or both ears $(+1$ or +2$)$, and occurrence of swelling in one or both forelimbs $(+1$ or +2$)$. The severity these lesions was graded from 0 to 5 , in which zero indicated the absence of lesions. Treatments were administered daily, p.o., beginning on the same day as arthritis induction and continued until day 21 after the induction. The data are expressed as median (range) for each group (6-7 animals) $* \mathrm{p}<0.05$, compared with AIA group (one-way ANOVA followed by Tukey test). Source: Authors.

\subsection{Treatment with the FOP reduced serum levels of nitric oxide in arthritic rats}

The serum concentration of nitric oxide (nitrite) in the AIA group was significantly higher compared with the normal 
group on day 21. The treatment of arthritic rats with 75 and $300 \mathrm{mg} / \mathrm{kg}$ FOP and $300 \mathrm{mg} / \mathrm{kg}$ FO reduced serum nitrite concentrations by $39.3 \%, 38.1 \%$, and $42.0 \%$, respectively, compared with the AIA control group. The treatment of arthritic rats with $3 \mathrm{mg} / \mathrm{kg}$ Npx also reduced serum nitrite concentrations by 40.6\%. Treatment with $37.5 \mathrm{mg} / \mathrm{kg}$ FOP and olive oil (Oo) did not alter serum nitrite concentrations compared with the AIA group (Figure 2).

Figure 1. Effect of fish oil preparation (FOP - 37.5, 75, 150, and $300 \mathrm{mg} / \mathrm{kg}$ ), pure fish oil (FO - $300 \mathrm{mg} / \mathrm{kg}$ ), olive oil (Oo), and naproxen (Npx - $3 \mathrm{mg} / \mathrm{kg}$ ) on left injected (A) and right non-injected (B) paws volume 1, 3, 6, 9, 13, 17 and 21 days after the induction of AIA. Treatments were administered daily, p.o., beginning on the same day as arthritis induction. The data are expressed as the mean \pm SEM of 6-7 animals for each experimental group.
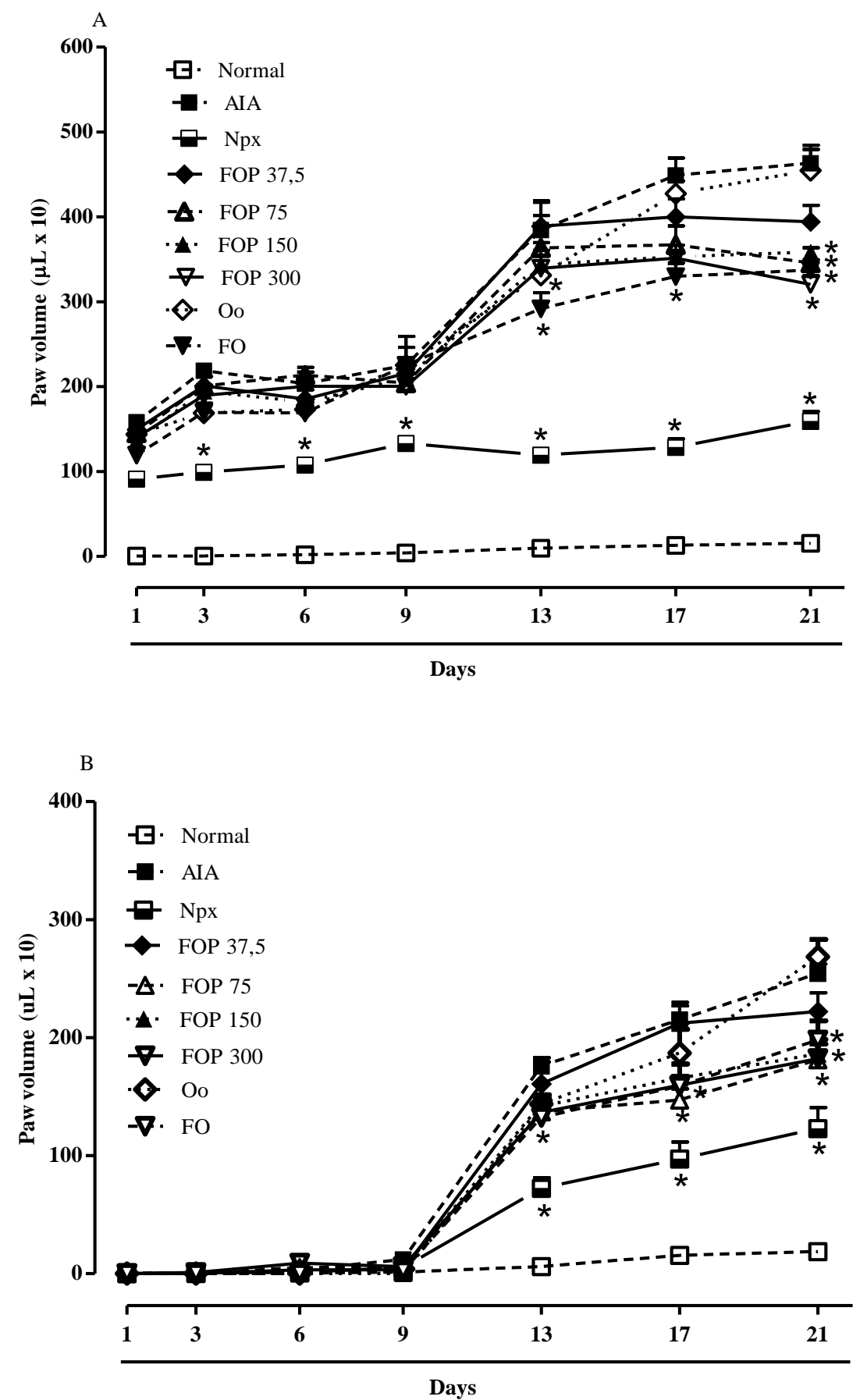

$* \mathrm{p}<0.05$ compared with control arthritic group (AIA) (one-way ANOVA followed by Tukey test). Source: Authors. 
Figure 2. Effect of fish oil preparation (FOP - 37.5, 75, 150, and $300 \mathrm{mg} / \mathrm{kg}$ ), pure fish oil (FO - $300 \mathrm{mg} / \mathrm{kg}$ ), olive oil (Oo), and naproxen $(\mathrm{Npx}-3 \mathrm{mg} / \mathrm{kg})$ on serum nitric oxide concentration (NO), 21 days after the induction of adjuvant-induced arthritis. The data are expressed as the mean \pm SEM of 6-7 animals for each experimental group. ${ }^{*}$ p $<0.05$, compared with normal group $(\mathrm{N}) ; * \mathrm{p}<0.05$, compared with control arthritic group (AIA) (one-way ANOVA followed by Tukey test).

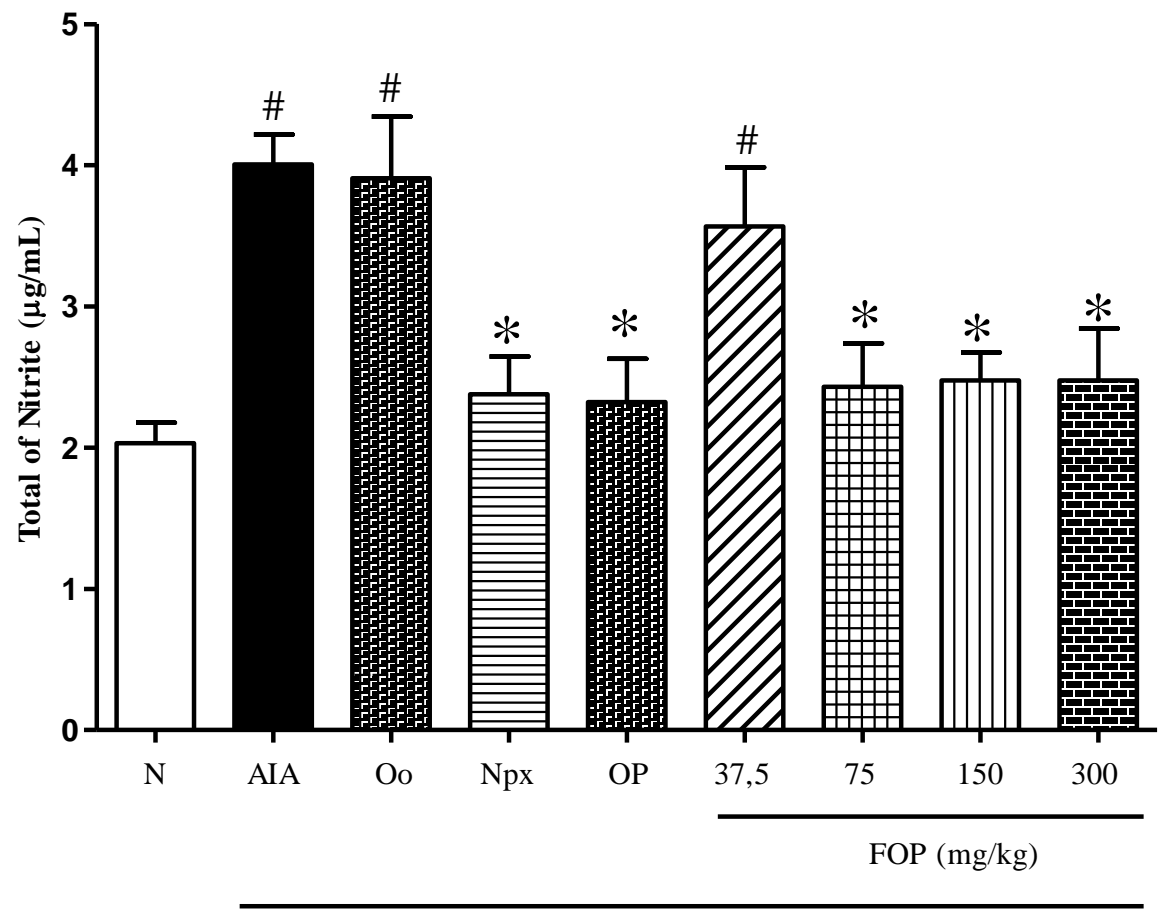

Arthritics

Source: Authors.

\subsection{Treatment with the FOP altered serum cytokine concentrations in arthritic rats}

Serum concentrations of proinflammatory cytokines (TNF, IL-1, IL-2, IL-6, and GM-CSF) on day 21 after arthritis induction increased in the AIA group compared with the normal group. The concentration of the antiinflammatory cytokine IL10 did not alter in the AIA group. Treatment with $300 \mathrm{mg} / \mathrm{kg}$ FOP, $300 \mathrm{mg} / \mathrm{kg} \mathrm{FO}$, and $3 \mathrm{mg} / \mathrm{kg} \mathrm{Npx}$ reduced the concentrations of TNF, IL-1, IL-2, IL-6, and GM-CSF compared with the AIA group (Figure 3). In arthritic rats that were treated with $300 \mathrm{mg} / \mathrm{kg}$ FOP and $300 \mathrm{mg} / \mathrm{kg}$ FO, the concentrations of IL-10 increased compared with the AIA group. Treatment with $3 \mathrm{mg} / \mathrm{kg} \mathrm{Npx}$ and Oo did not alter the concentrations of IL-10 (Figure 3).

\subsection{Treatment with the FOP reduced histopathological changes in cartilage and the synovial membrane in the} femorotibial joint and bone matrix

Histological analyses of the left and right femorotibial joints by HE staining in the normal group revealed a preserved and intact morphological aspect of both articular cartilage and the synovial membrane (Figure 4A, 4B; Figure 5A, 5B). In the AIA control group, severe changes in the left and right joints were observed on day 21 after arthritis induction, manifested as thickening of the articular cartilage, the arrangement of chondrocytes in columns, hyperplasia of the synovial membrane and cartilage, and the presence of inflammatory infiltrates with pannus formation (Figure 4C, 4D; Figure 5C, 5D). In arthritic rats that were treated with Npx (Figure 4G, 4H; Figure 5G, 5H), 300 mg/kg FOP (Figure 4I, 4J; Figure 5I, 5J) and 300 mg/kg FO (Figure 4K, 4L; Figure 5K, 5L), the left and right joints were more preserved compared with the AIA control group. Arthritic 
rats that were treated with Oo did not present any changes.

Figure 3. Effect of fish oil preparation (FOP - 37.5, $300 \mathrm{mg} / \mathrm{kg}$ ), pure fish oil (FO - $300 \mathrm{mg} / \mathrm{kg}$ ), olive oil (Oo), and naproxen $(\mathrm{Npx}-3 \mathrm{mg} / \mathrm{kg})$ on serum concentration of proinflammatory cytokines (TNF, IL-1, IL-2, IL-6, and GM-CSF) and antiinflammatory cytokine (IL-10), 21 days after the induction of adjuvant-induced arthritis. The data are expressed as the mean \pm SEM of 5-6 animals for each experimental group. ${ }^{*} \mathrm{p}<0.05$, compared with normal group $(\mathrm{N}) ;{ }^{*} \mathrm{p}<0.05$, compared with control arthritic group (AIA) (one-way ANOVA followed by Tukey test).

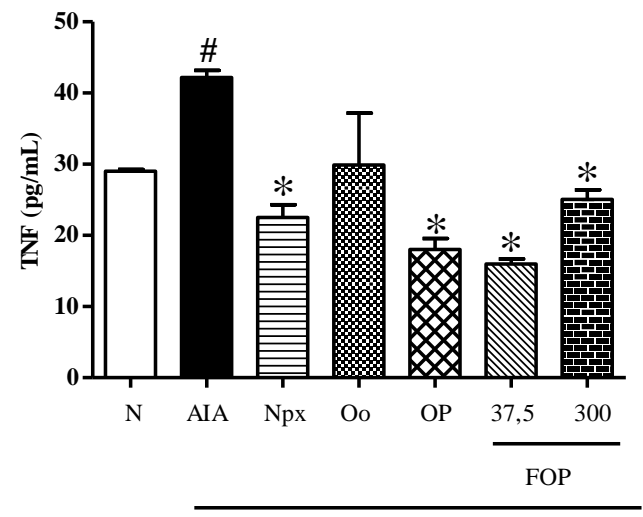

Arthritics

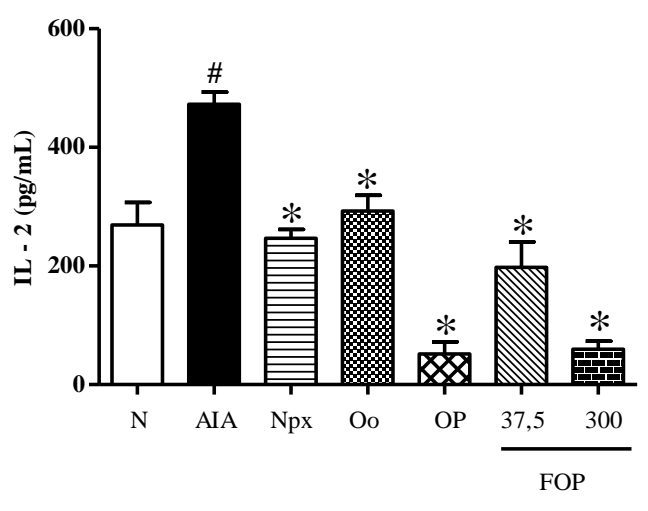

Arthritics

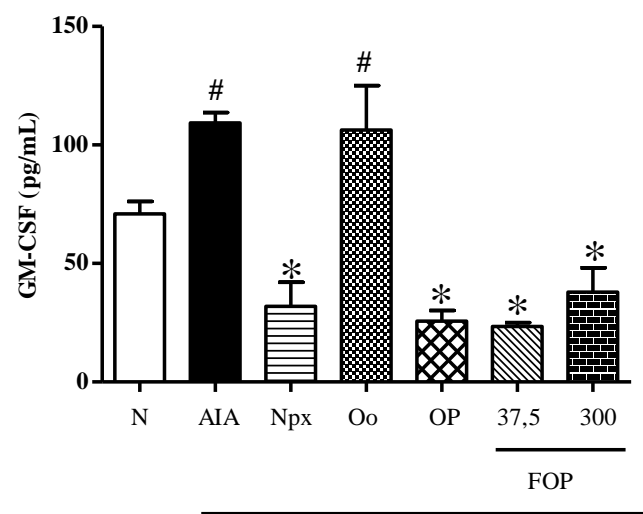

Arthritics

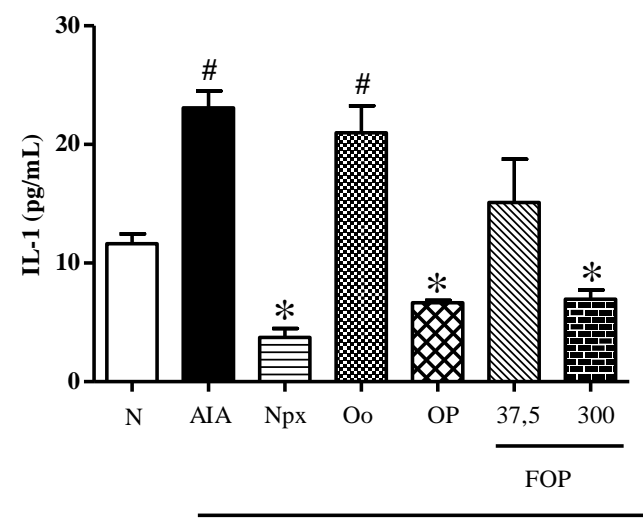

Arthritics

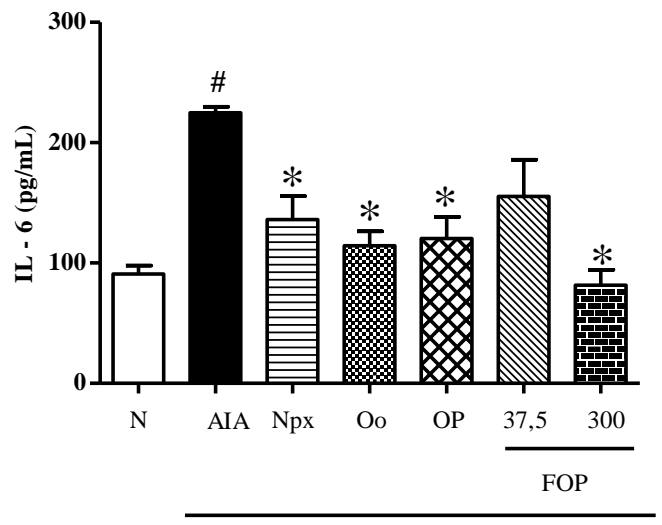

Arthritics

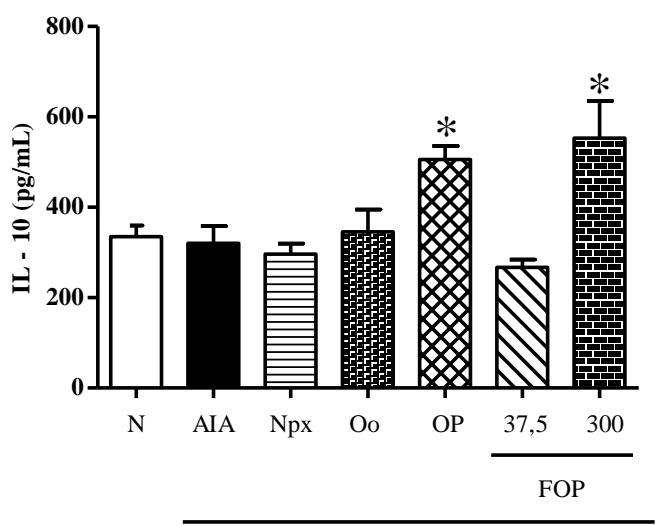

Arthritics

Source: Authors. 
Figure 4. Photomicrographs of left femorotibial articulations in groups: N- normal rats (A-B), AIA- arthritics rats (C-D), Ooarthritics rats treated with olive oil (E-F), Npx- arthritics rats treated with naproxen at $3 \mathrm{mg} / \mathrm{kg}$ (G-H), FOP- arthritics rats treated with the FOP at $300 \mathrm{mg} / \mathrm{kg}$ (I-J), FO- arthritics rats treated with pure FO at $300 \mathrm{mg} / \mathrm{kg}$ (K-L). General aspects: Both (A) articular cartilage (AC) and (B) synovial membrane (SM) preserved, with intact morphological aspect. (C-D and E-F) thickening of the articular cartilage (arrow), the arrangement of chondrocytes in columns, presence of inflammatory infiltrates (dotted arrow), hyperplasia of the synovial membrane and cartilage, and the with pannus formation (arrowhead). Npx, FOP and FO decreased inflammatory infiltrate, synovial membrane hyperplasia and cartilage (G-H, I-J, K-L). Tibia (TB); femorotibial articulations (FM); synovial membrane (SM); articular cartilage (CA). The images were captured at 40 magnification. Hematoxylin/eosin staining.

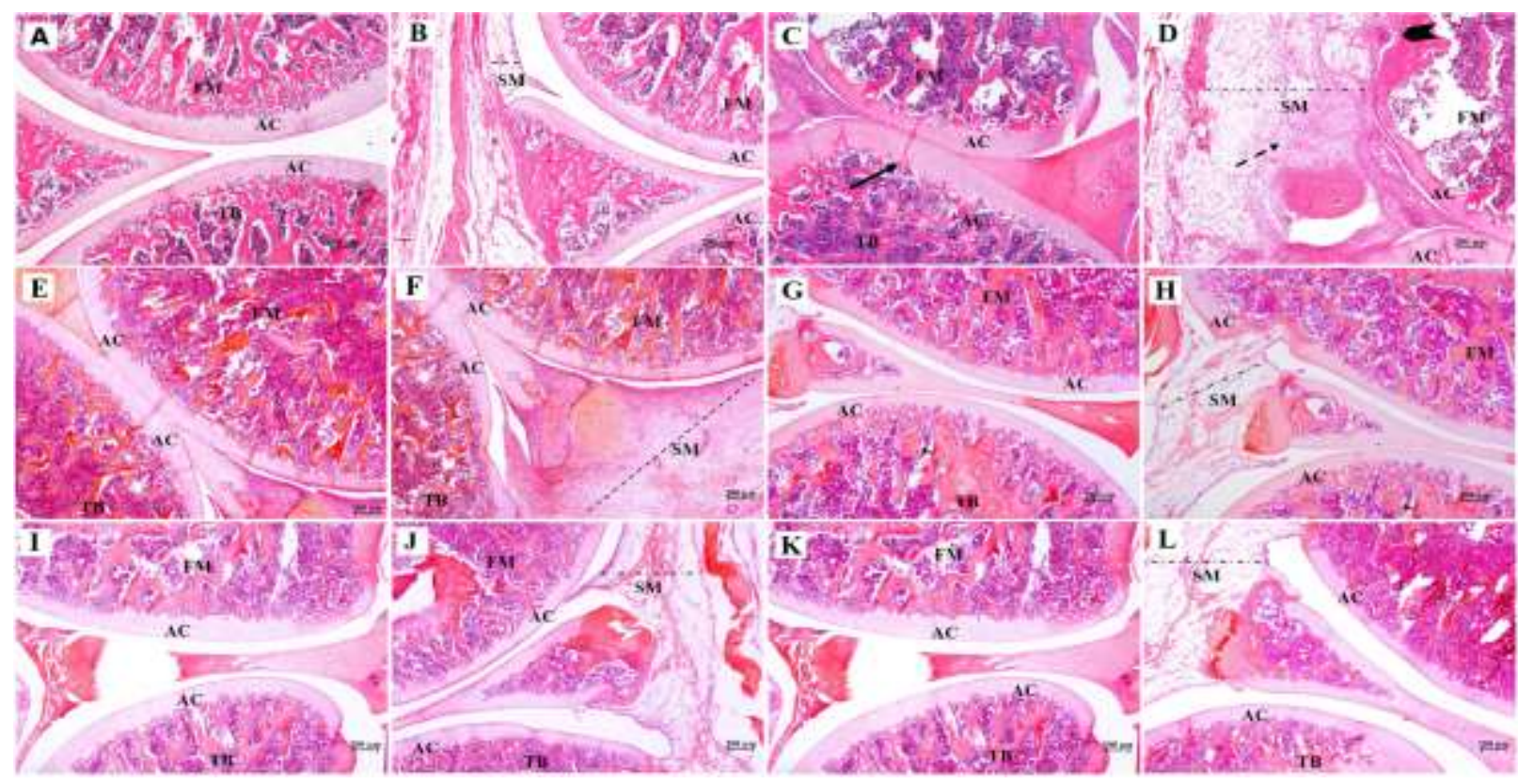

Source: Authors. 
Figure 5. Photomicrographs of right femorotibial articulations in groups: N- normal rats (A-B), AIA- arthritics rats (C-D), Oo- arthritics rats treated with olive oil (E-F), Npx- arthritics rats treated with naproxen at $3 \mathrm{mg} / \mathrm{kg}$ (G-H), FOP- arthritics rats treated with the FOP at $300 \mathrm{mg} / \mathrm{kg}$ (I-J), FO- arthritics rats treated with pure FO at $300 \mathrm{mg} / \mathrm{kg}$ (K-L). General aspects: Both (A) articular cartilage (AC) and (B) synovial membrane (SM) preserved, with intact morphological aspect. (C-D and E-F) thickening of the articular cartilage (arrow), the arrangement of chondrocytes in columns, presence of inflammatory infiltrates (dotted arrow), hyperplasia of the synovial membrane and cartilage, and the with pannus formation (arrowhead). Npx, FOP and FO decreased inflammatory infiltrate, synovial membrane hyperplasia and cartilage (G-H, I-J, K-L). Tibia (TB); femorotibial articulations (FM); synovial membrane (SM); articular cartilage (CA). The images were captured at 40 magnification. Hematoxylin/eosin staining.

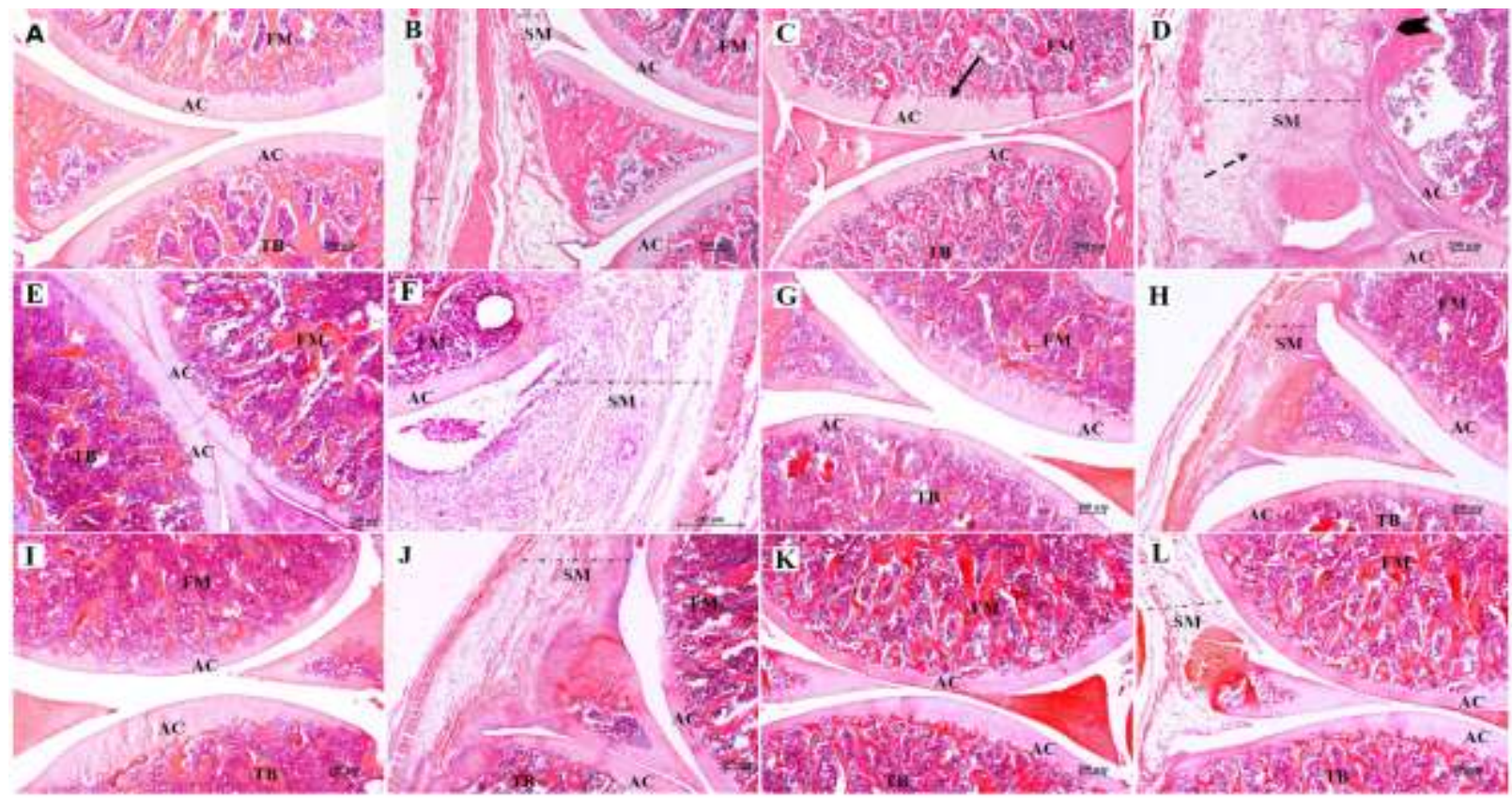

Source: Authors.

Inflammatory infiltrate scores for the synovial membrane and changes in articular cartilage are shown in Table 2. The AIA group had the maximum score for changes in cartilage (5 points), indicating a predominance of chondrocytes that were distributed in columns, irregularities in the surface of the articular membrane, and invasion of the pannus. The AIA control group also had a maximum score (4 points) for cell infiltrates, in which the synovial membrane of the right and left joints was hyperplastic and invaded by very intense inflammatory infiltrates. Arthritic rats that were treated with FOP, FO, and Npx had significantly lower scores for right and left cartilage $(\leq 4$ points) and inflammatory infiltrate $(\leq 3$ points $)$ compared with the AIA control group. Arthritic rats that were treated with Oo did not present any changes. 
Table 2. Histological scores for alterations in articular cartilage and inflammatory infiltrate in the synovial membrane of the femorotibial articulation 21 days after the induction of adjuvant-induced arthritis.

\begin{tabular}{cccccc}
\hline & \multicolumn{2}{c}{ Left } & & \multicolumn{2}{c}{ Right } \\
\cline { 2 - 3 } \cline { 5 - 6 } \cline { 5 - 6 } & $\begin{array}{c}\text { Cartilage } \\
\text { damage }\end{array}$ & $\begin{array}{c}\text { Inflammatory } \\
\text { infiltrate }\end{array}$ & & $\begin{array}{c}\text { Cartilage } \\
\text { damage }\end{array}$ & $\begin{array}{c}\text { Inflammatory } \\
\text { infiltrate }\end{array}$ \\
\cline { 3 - 5 } AIA & $5(4-5)$ & $4(3-4)$ & & $5(5-5)$ & $4(3-4)$ \\
Oo & $4(3-5)$ & $4(3-4)$ & & $4(4-5)$ & $3(3-4)$ \\
Npx & $3(2-4)^{*}$ & $2(1-2)^{*}$ & & $3(3-5)^{*}$ & $1(1-3)^{*}$ \\
FOP & $3(2-5)^{*}$ & $2(1-2)^{*}$ & & $2(2-5)^{*}$ & $2(1-3)^{*}$ \\
FO & $3(2-5)^{*}$ & $2(1-2)^{*}$ & & $2(2-5)^{*}$ & $2(1-4)^{*}$ \\
\hline
\end{tabular}

(AIA) control arthritics rats, (Oo) arthritic rats treated with olive oil, (Npx) arthritic rats treated with naproxen-3mg/kg, (FOP) arthritic rats treated with the fish oil preparation $-300 \mathrm{mg} / \mathrm{Kg}$, (FO) arthritic rats treated with pure fish oil - $300 \mathrm{mg} / \mathrm{Kg}$. Histological scores for cartilage damage in femorotibial articulations in rats was graded from 0 to 5 points (Ritter et al., 2017) ${ }^{1}: 0$ (absence of damage), 1 (increased number of chondrocytes distributed in columns), 2 (increased number of chondrocytes distributed in columns and also disorganized chondrocytes), 3 (decreased number of chondrocytes with disorganized distribution), 4 (change in the number of chondrocytes and disorganized articular membrane superficies), and 5 (change in the number of chondrocytes, disorganized articular membrane superficies, and pannus formation in articular cartilage). Histological scores for the frequency of inflammatory infiltrate in the synovial membrane in femorotibial articulations in rats were graded from 0 to 4 points (Ritter et al., 2017): (0) absence of inflammatory infiltrate, normal synovial membrane; (1) low inflammatory infiltrate scattered across the tissue; (2) moderate inflammatory infiltrate scattered across the tissue with small groups of cells; (3) high inflammatory cells distributed throughout the tissue; (4) intense inflammatory infiltrate distributed throughout the tissue with evident membrane thickening. The data are expressed as the median (range) for each group. $* p<0.05$, compared with control arthritic group (AIA) (one-way ANOVA followed by Tukey test). Source: Authors.

The morphometric analysis showed that the AIA group exhibited hyperplasia of cartilage and the synovial membrane compared with the normal group. In arthritic rats that were treated with $300 \mathrm{mg} / \mathrm{kg}$ FOP and $300 \mathrm{mg} / \mathrm{kg}$ FO, a reduction of the thickness of cartilage and the synovial membrane was observed for both the left and right joints (Figure 6A, 6B).

The analysis of the area that was occupied by the organic matrix in subchondral bone in sections that were stained with sirius red revealed that the average area of the epiphyses of the tibia and femur was $127.824 \mu \mathrm{m}^{2}$ (left side) and $106.818 \mu \mathrm{m}^{2}$ (right side) in the normal group, with reductions of approximately $37 \%$ and $42 \%$, respectively, in the AIA control group. In arthritic rats that were treated with $300 \mathrm{mg} / \mathrm{kg}$ FOP, $300 \mathrm{mg} / \mathrm{kg}$ FO, and $3 \mathrm{mg} / \mathrm{kg} \mathrm{Npx}$, the reductions were $29 \%$, 28\%, and $21 \%$, respectively, on the left side and $38 \%, 38 \%$, and $38 \%$, respectively, on the right side. Arthritic rats that were treated with Oo exhibited no changes (Figure 7). 
Figure 6. Thickness of the left and right synovial membrane (A), and thickness of the left and right articular cartilage (B) 21 days after the induction of adjuvant-induced arthritis. (N) normal rats, (AIA) control arthritics rats, (FOP) arthritic rats treated with the fish oil preparation - $300 \mathrm{mg} / \mathrm{Kg}$, (FO) arthritic rats treated with pure fish oil - $300 \mathrm{mg} / \mathrm{Kg}$, (Oo) arthritic rats treated with olive oil, $(\mathrm{Npx})$ arthritic rats treated with naproxen-3mg/kg. The data are expressed as the mean \pm SEM of 5-6 animals for each experimental group. ${ }^{\#} \mathrm{p}<0.05$, compared with normal group $(\mathrm{N}){ }^{*} \mathrm{p}<0.05$, compared with control arthritic group (AIA) (one-way ANOVA followed by Tukey test).
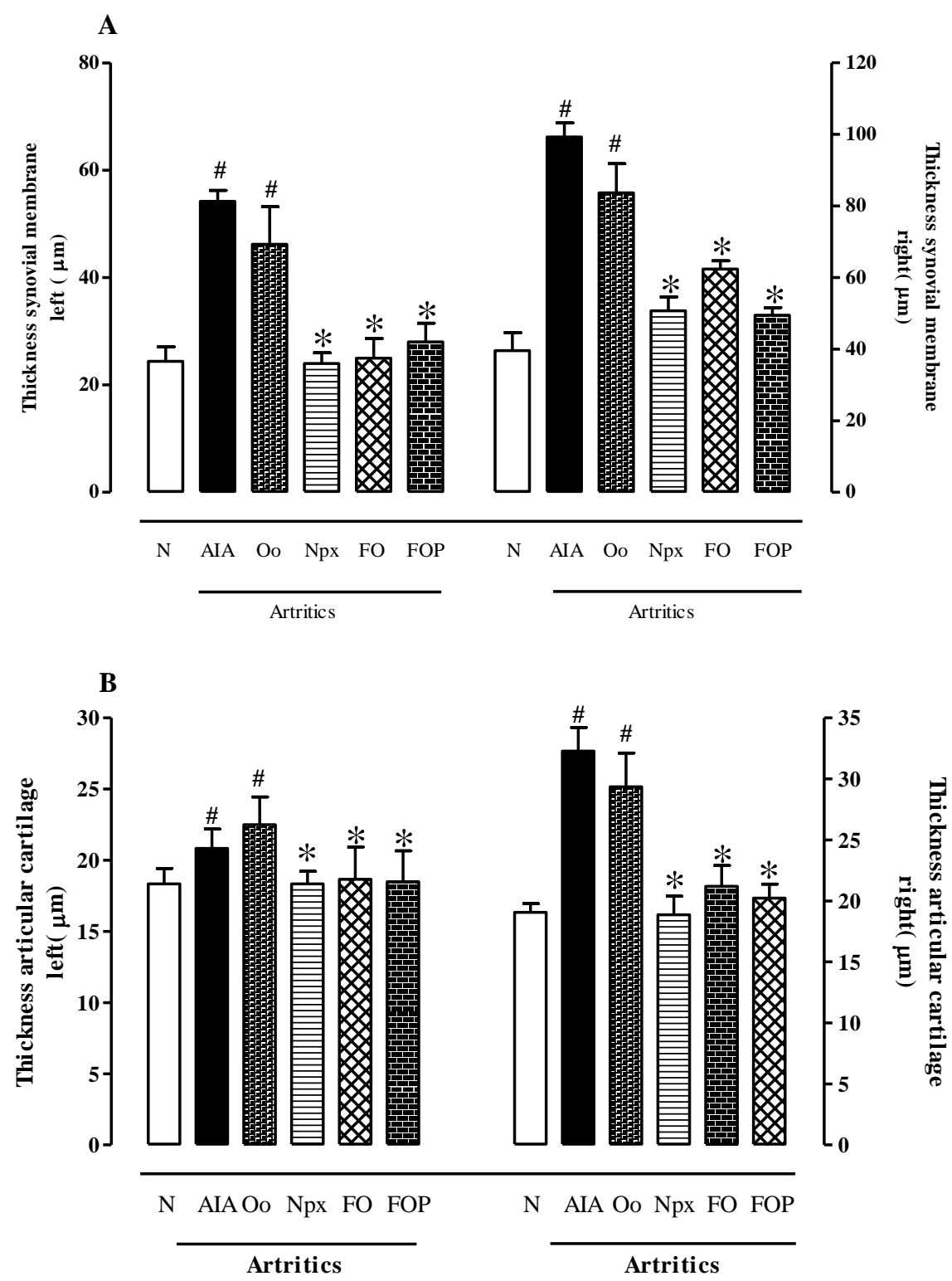

Source: Authors. 
Figure 7. Organic matrix area of in the subchondral bone in normal rats (N), control arthritic group (AIA) and arthritics rats treated with: olive oil (Oo), naproxen (Npx-3 mg/kg), fish oil preparation (FOP-300 mg/kg) and pure fish oil (FO-300 mg/kg), 21 days after the induction of adjuvant-induced arthritis. The data are expressed as the mean \pm SEM of 6-7 animals for each experimental group. ${ }^{*} \mathrm{p}<0.05$, compared with normal group; ${ }^{*} \mathrm{p}<0.05$, compared with $\mathrm{C}$ group (one-way ANOVA followed by Tukey test).

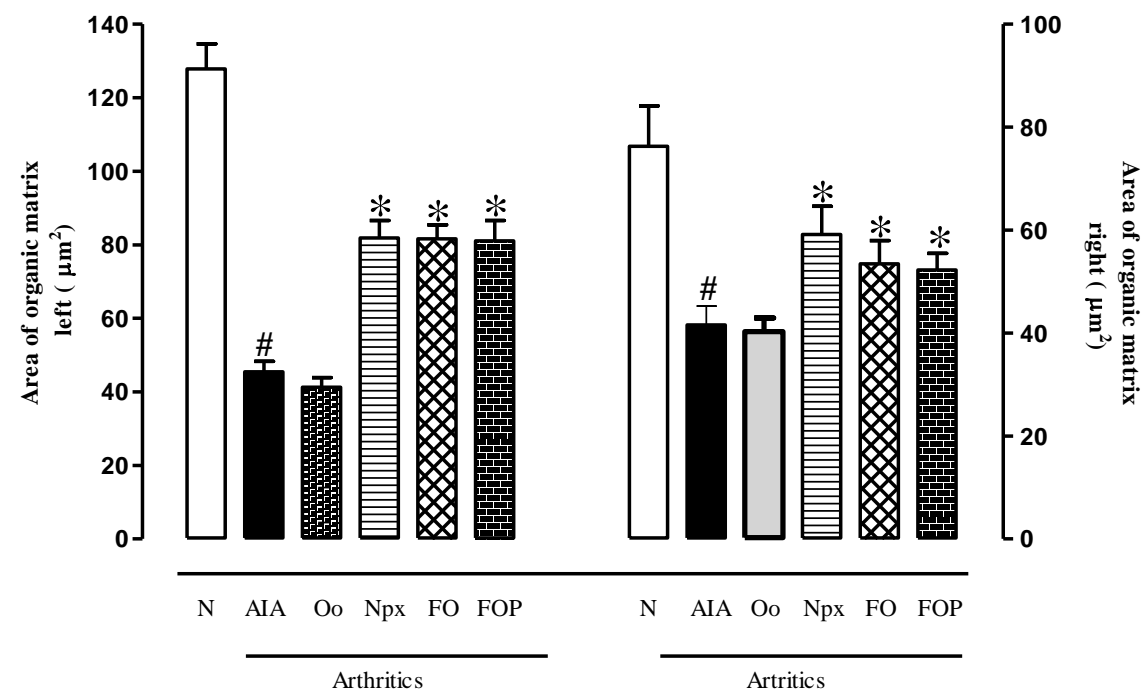

Source: Authors.

\section{Discussion}

The present study investigated the effects of a FOP on arthritis that was induced by CFA in rats. Inflammatory and histopathological parameters were evaluated. The FOP consisted of fish oil diluted in olive oil, which was used to enable the administration of FO in very low amounts ( 35 and $75 \mathrm{mg} / \mathrm{kg}$ ). The choice of olive oil (Oo) to dilute the FO was based on our previous studies that evaluated the beneficial effects of FO on the acute inflammatory response and recruitment of leukocytes into the joint cavity in arthritic rats (Ames et al., 2017; Ames et al., 2020; Arruda et al., 2017; Estevão-Silva et al., 2016).

The inclusion of a group of arthritic animals that were treated with pure FO was important in the present study because no differences in the effect were found between the FOP and FO treatments at equivalent amounts ( $300 \mathrm{mg} / \mathrm{kg})$. This indicates that the dilution process did not interfere with the effectiveness of FO.

The FOP inhibited the development of AIA. Clinical signals of the disease, such as paw edema, secondary lesions, and histopathological alterations that are usually caused by the disease were prevented. One possibility is that these effects could be at least partially attributable to the ability of the FOP to modulate the production or release of nitric oxide and cytokines that participate in the pathophysiology of AIA, which was observed in the present study.

Corroborating the present results, studies showing that the FO inhibited the inflammatory response in rats with collagen-induced arthritis and the inflammatory response that was induced by polysaccharide A (derived from Streptococcus pyrogenes) (Ierna et al., 2010; Leslie et al., 1988; Volker et al., 2000).

Moreover, clinical studies demonstrated that treatment with FO can attenuate clinical signs and symptoms in human rheumatoid arthritis patients (Calder, 2014;. Calder; 2010; He et al., 2020, Mattos \& Andrade, 2006; Simopoulos, 2002).

Treatment with the FOP at 75, 150, and $300 \mathrm{mg} / \mathrm{kg}$ and pure FO at $300 \mathrm{mg} / \mathrm{kg}$ similarly inhibited arthritis. Previous studies reported that treatment with a FOP at doses of 30 and $300 \mathrm{mg} / \mathrm{kg}$ similarly reduced the development of acute inflammation, indicating that the FOP may have a ceiling effect, suggesting that higher doses may be not necessary for the treatment of some diseases (Arruda et al., 2017). 
In the AIA model, a severe joint inflammatory process occurs, with the participation of various inflammatory cells and chemical mediators. In this model, the synovial membrane becomes hyperplastic and rich in inflammatory cells, forming a pannus between bone and cartilage and promoting angiogenesis and the invasion of neighboring tissues that contribute to selfperpetuation and greater damage to cartilage and bone (Leslie et al., 1988; Paleolog, 2002). Cartilage degradation occurs when cytokines (e.g., TNF, IL-1, and IL-6) activate synoviocytes and chondrocytes, which begin to secrete matrix metalloproteinases that degrade collagen, elastin, glycoproteins, and articular proteoglycans (Boissier et al., 2012; Smolen \& Steiner, 2003).

Furthermore, chondrocyte apoptosis occurs through the actions of proinflammatory cytokines and reactive nitrogen intermediaries that lead to greater cartilage destruction. Bone erosion also occurs through the constant release of cytokines, such as GM-CSF, and activation of the transcription factor nuclear factor- $\mathrm{kB}$, which promotes the differentiation of osteoclasts and cellular invasion of the surface adjacent to cartilage. Osteoclasts destroy mineralized tissues, such as cartilage and subchondral bone, which are replaced by inflammatory tissue (Mcinnes \& Schett, 2011).

Nitric oxide plays an important role in many cellular events that are associated with the inflammatory response by activating cytotoxic effector cells, inducing the apoptosis of chondrocytes and destruction of cartilage and bone (Nakagawa et al., 2010; Pal et al., 2015). TNF, IL-1, IL-6, and GM-CSF can stimulate the production of other inflammatory cytokines and adhesion molecules and activation of chondrocytes and osteoclasts that also contribute to joint destruction 'Assier et al, 2010; Boissier et al., 2012; Cascão et al., 2010; Dayer \& Choy, 2010; Lally et al, 2005; Mcinnes \& Schett, 2011)

Previous studies have shown that IL-6 knockout mice have less severe joint damage (Rabe et al., 2008) compared with control animals. IL-10 is the main immunoregulatory cytokine (Sakata et al., 2015) that reduces the inflammatory response that is mediated by T-lymphocytes and proinflammatory cytokines (Mingomataj \& Bakiri, 2016). Cytokines are important at the beginning of, and in the transition to, the chronic phase of arthritis, indicating the importance of these molecules as therapeutic targets for the treatment of AIA (Leslie et al., 1988; El-Sayyad et al., 2021).

The reduction of joint damage and inflammatory infiltrate in cartilage in animals that were treated with the FOP may be partially related to the modulatory activity of these inflammatory mediators, including the downregulation of TNF, IL-1, IL2, IL-6, and GM-CSF and upregulation of IL-10.

Histological evaluation of the femorotibial joint in arthritic rats showed that the FOP reduced morphological and morphometric alterations in cartilage and bone. These effects can also be attributable to a decrease in the recruitment of leukocytes to the joints (Estevão-Silva et al., 2016), in addition to alterations of serum levels of cytokines and nitric oxide. Corroborating these findings in a collagen-induced arthritis model in mice, FO reduced inflammatory infiltrate, synovial hyperplasia, and cartilage and bone erosion (Ierna et al., 2010).

Several studies have shown that EPA and DHA have antiinflammatory and immunomodulatory effects by decreasing the production of eicosanoids, cytokines, and nitric oxide and decreasing the expression of adhesion molecules, mitogenactivated protein kinase $\mathrm{p} 38$, nuclear factor- $\mathrm{KB}$, and peroxisome proliferator-activated receptors (Ames et al., 2017; Arruda et al., 2017; Bouwens et al., 2009; Calder, 2006; DeCaterina \& Madonna, 2004; Ferrucci et al., 2006; Giudetti \& Cagnazzo, 2012; Lima-Garcia et al., 2011; Miles \& Calder, 2012; Nobre et al., 2013; Nohe et al., 2003). Fish oil also suppressed the expression of matrix metalloproteinases, degradation of proteoglycans, and expression of cyclooxygenase- 2 and mitogenactivated protein kinase p38, leading to a reduction of tissue damage (Hansen et al., 2008; Miles \& Calder, 2012; Penglis et al., 2000).

In the present study, the modulation of cytokines was associated with improvements in inflammatory, clinical, and histological parameters in animals that were treated with the FOP, indicating that the FOP be a promising treatment for arthritis and possibly other chronic diseases. Overall, these findings are important because most anti-arthritic agents reduce inflammation, but they do not always improve or prevent cartilage damage and bone erosion. 


\section{Conclusion}

The FOP inhibited the development of AIA preventing the clinical signals of the disease, such as paw edema, secondary lesions, and histopathological alterations that are usually caused by the disease.These effects could be at least partially attributable to inhibitory and modulatory actions of the FOP on the production and release of nitric oxide and cytokines (i.e., downregulation of TNF, IL-1, IL-2, IL-6, and GM-SCF and upregulation of IL-10) that participate in the pathophysiology of AIA. For all this, we propose that the fish oil might represent an interesting and promising treatment alternative for arthritis, contributing to the attenuation and the progression of this chronic inflammatory disease.

\section{Acknowledgments}

This study was supported by grants from CAPES (Coordenadoria de Aperfeiçoamento de Pessoal de Nível Superior), CNPq (Conselho Nacional de Desenvolvimento Científico e Tecnológico) and FA (Fundação Araucária/PR), Brazil.

\section{References}

Ames, F. Q, Sato, F., Castro, L. V., Arruda, L. L. M., Rocha, B. A., Cuman, R. K. N., Baesso, M. L, \& Bersani-Amado, C. A. (2017). Evidence of antiinflammatory effect and percutaneous penetration of a topically applied fish oil preparation: a photoacoustic spectroscopy study. Journal of Biomedical Optics, 22(5), 055003.

Ames, F. Q., Bracht, L., Sato, F., Castro-Hoshino, L. V., Rocha, B. A., Oliveira, L. A., Lima, E. P., Cuman, R. K. N., Baesso, M. L., \& Bersani-Amado, C. A. (2020). Fish oil preparation inhibits leukocyte recruitment and bands that characterize inflamed tissue in a model of phenol-induced skin inflammation: percutaneous penetration of a topically applied preparation demonstrated by photoacoustic spectroscopy. Natural Product Research, 34(16), $2341-2345$.

Arruda, L. L. M., Ames, F. Q., Morais, D. R., Grespan, R., Gil, A. P. M., Silva, M. A. R. C. P., Visentainer, J. V., Cuman, R. K. N., \& Bersani-Amado, C. A. (2017). A single administration of fish oil inhibits the acute inflammatory response in rats. Asian Pacific Journal of Tropical Medicine, 10(8), 765-772.

Assier, E., Boissier, M. C. J. M., \& Dayer, J. M.(2010). Interleukin-6: from identification of the cytokine to development of targeted treatments. Joint Bone Spine, 77(6), 532-536.

Boissier, M., Semerano, L., Challal. S., Saidenberg-Kermanac'h, N., \& Falgarone, G. (2012). Rheumatoid arthritis: from autoimmunity to synovitis and joint destruction. Journal of Autoimmunity, 39(3), 222-228.

Bouwens, M., Rest, O. V. D., Dellschaft, N., Bromhaar, M. G., Groot, L. C. P. G. M., Geleijnse, J. M., Müller, M., \& Afman, L. A. (2009). Fish-oil supplementation induces antiinflammatory gene expression. American Journal of Clinical Nutrition, 90(2), 415-424.

Calder, P. C. (2006). Long-chain polyunsaturated fatty acids and inflammation. Scandinavian Journal of Food and Nutrition, 50, 54-61.

Calder, P. C. (2010). Omega-3 fatty acids and inflammatory processes. Nutrients, 2(3), 355-374.

Calder, P. C. (2014). Marine omega-3 fatty acids and inflammatory processes: Effects, mechanisms and clinical relevance. Biochimica et Biophysica Acta, $851,469-484$.

Cascão, R., Rosário, H., Souto-Carneiro, M., \& Fonseca, J. (2010). Neutrophils in rheumatoid arthritis: More than simple final effectors. Autoimmunity Reviews, 2010; 9(8), 531-535.

Dayer, J. M., \& Choy, E. (2010). Therapeutic targets in rheumatoid arthritis: the interleukin-6 receptor. Rheumatology (Oxford). 49, 15-24.

DeCaterina, R., \& Madonna, R. M. M. (2004). Effects of omega-3 fatty acids on cytokines and adhesion molecules. Current Atherosclerosis Reports, 6, 485491.

El-Sayyad, S. M., Ali, M. A., Kandil, L. S., Ragab, G. M., \& Abdelhamid Ibrahim, S. S. (2021). Metformin and omega-3 fish oil elicit anti-inflammatory effects via modulation of some dysregulated micro RNAs expression and signaling pathways in experimental induced arthritis. International Immunopharmacology, 2021, 92:107362. 10.1016/j.intimp.2020.107362

Estevão-Silva, C. F., Ames, F. Q., Silva-Comar, F. M. S., Kummer, R., Tronco, R. P., Cuman, R. K. N., \& Bersani-Amado, C. A. (2016). Fish oil and adjuvant-induced arthritis: inhibitory effect on leukocyte recruitment. Inflammation, 39(1), 320-326.

Ferrucci, L., Cherubini, A., Bandinelli, S., Bartali, B., Corsi, A., Lauretani, F., Martin, A., Andres-Lacueva, C., Senin, U., \& Guralnik, J. M. (2006). Relationship of plasma polyunsaturated fatty acids to circulating inflammatory markers. Journal of Clinical Endocrinology \& Metabolism, 91(2), 439-446.

Giudetti, A. M., \& Cagnazzo, R. (2012). Beneficial effects of n-3 PUFA on chronic airway inflammatory diseases. Prostaglandins Other Lipid Mediators, 99, 57-67.

Hansen, R. A.,. Harris, M. A., Pluhar, E., Motta, T., Brevard, S., Ogilvie, G., Fettman, M. J., \& Allen, K. G. D. (2008). Fish oil decreases matrix metalloproteinases in knee synovia of dogs with inflammatory joint disease. Journal of Nutritional Biochemistry, 19(2), 101-108. 
He, Z., Kwek, E., \& Chen, Z. Y. (2020). Lipids and Arthritis, The Chinese University of Hong Kong, Hong Kong, China Bailey's Industrial Oil and Fat Products, 7th Edition, edited by Fereidoon Shahidi. Copyright@John Wiley \& Sons, Ltd. doi:0.1002/047167849X.bio108

Ierna, M., Kerr, A., Scales, H., Berge, K., \& Griinari, M. (2010). Supplementation of diet with krill oil protects against experimental rheumatoid arthritis. BMC Musculoskelet Disorders, 11, 136-146.

LaBranche, T. P., Jesson, M. I., Radi, Z., Storer, C.E., Guzova, J., Bonar, S. L., Thompson, J. M., Happa, F. A., Stewart, Z. S., Zhan, Y., Bollinger, C. S., Bansal, P. N., Wellen, J. W., Wilkie, D. P., Bailey, S. A., Symanowicz, P. T., Hegen, M., Head, R. D., Kishore, N., Mbalaviele, G., \& Meyer, D. M. (2012). JAK inhibition with tofacitinib suppresses arthritic joint structural damage through decreased RANKL production. Arthritis \& Rheumatology, 64(11), 35313542

Lally, F., Smith, E., Filer, A., Stone, M. A., Shaw, S., Nash, G. B., Buckley, C. D, \& Ed Rainger G. (2005). A novel mechanism of neutrophil recruitment in a coculture model of the rheumatoid synovium. Arthritis \& Rheumatism, 52(11), 3460-3469.

Leslie, C., Conte, J., Hayes, K., \& Cathcart, E. (1988). A fish oil diet reduces the severity of collagen induced arthritis after onset of the disease. Clinical and Experimental Immunology, 1988;73(2), 328-332.

Lima-Garcia, J., Dutra, R., Silva, K., Motta, E., Campos, M., \& Calixto, J. B. (2011). The precursor of resolvin D series and aspirin-triggered resolvin D1 display anti-hyperalgesic properties in adjuvant-induced arthritis in rats. British Journal of Pharmacology, 164, 278-293.

Mattos, P., \& Andrade, M. (2006). Ácidos graxos n-3 : um link entre eicosanóides, inflamação e imunidade. Mn-Metabólica, 8(3), 135-143. Mcinnes, B., Schett, G. (2011). The pathogenesis of rheumatoid arthritis. New England Journal of Medicine, 365: 2205-2221.

Mcinnes, B., \& Schett, G. (2011). The pathogenesis of rheumatoid arthritis. New England Journal of Medicine, 365: 2205-2221.

Miles, E., \& Calder, P. C. (2012). Influence of marine n-3 polyunsaturated fatty acids on immune function and a systematic review of their effects on clinical outcomes in rheumatoid arthritis. British Journal of Nutrition, 107, S171-84.

Mingomataj, E., \& Bakiri, A. (2016). Regulator Versus Effector Paradigm: Interleukin-10 as indicator of the switching response. Clinical Reviews in Allergy \& Immunology, 50(1), 97-113.

Mori, T, Watts, G., Burke, V., Hilme, E., Puddey, I., \& Beilin, L. (2000). Differential effects of eicosapentaenoic acid and docosahexaenoic acid on vascular reactivity of the forearm microcirculation. Circulation, 102, 1264-1269.

Nakagawa, S., Arai, Y., Mazda, O., Kishida, T., Takahashi, K., Sakao, K., Saito, M., Honjo, K., Imanishi, J., \& Kubo, T. (2010). N-acetylcysteine prevents nitric oxide-induced chondrocyte apoptosis and cartilage degeneration in an experimental model of osteoarthritis. Journal of Orthopaedic Research, 28, 156163.

Nobre, M. E. P., Correia, A. O., Borges, M. B., Sampaio, T. M. A., Chakraborty, S. A., Gonçalves, D; O., Brito. G; A, Almeida, L. K., Felipe, C. F. B., Lucetti, D. L., Arida, R. M., \& Viana, G. S. B. (2013). Eicosapentaenoic acid and docosahexaenoic acid exert anti-inflammatory and antinociceptive effects in rodents at low doses. Nutrition Research, 33(5), 422-433.

Nohe, B., Johannes, T., \& Dieterich, H. (2003). Antiinflammatory effects of omega-3 fatty acids vary at different stages of inflammation. American Journal of Physiology-Heart and Circulatory Physiology, 285, 2248-2250.

Pal, R., Chaudhary, M., Tiwari, P., Babu, S., \& Pant, K. (2015). Protective role of theophylline and their interaction with nitric oxide (NO) in adjuvant-induced rheumatoid arthritis in rats. International Immunopharmacology, 29(2), 854-862.

Paleolog, E. (2002). Angiogenesis in rheumatoid arthritis. Arthritis Research, 4, 81-90.

Penglis, P., Cleland, L., Demasi, M., Caughey, G., \& James, M. (2000). Differential regulation of prostaglandin E 2 and thromboxane A 2 production in human monocytes: implications for the use of cyclooxygenase inhibitors. Journal of Immunology, 165(3),1605-1611.

Rabe, B., Chalaris, A., May, U., Waetzig, G., Seegert, D., Williams, A., Jones, S. A., John, S. R., \& Scheller, J. (2008). Transgenic blockade of interleukin 6 transsignaling abrogates inflammation. Blood, 111(3), 1021-1029.

Ritter, A. M. V., Hernandes, L., Rocha, B. A, Estevão-Silva, C. F., Wisniewski-Rebecca, E. S., Cezar, J. S., Caparroz-Assef, S. M., Cuman, R. K. N., \& Bersani-Amado, C. A. (2017). Anethole reduces inflammation and joint damage in rats with adjuvant-induced arhritis. Inflammation Research, 66, $725-737$.

Rosenthale, M. E. (1970). A comparative study of the Lewis and Sprague Dawly rat in adjuvant arthritis. Arch Int Pharmacodyn et Therapie, 188(1), 14-22.

Sakata, S., Hayashi, S., Fujishiro, T., Kawakita, K., Kanzaki, N., Hashimoto, S., Iwasa, K., Chinzei, N., Kihara, S., Haneda, M., Ueha, T., Nishiyama, T., Kuroda, R., \& Kurosaka, M. (2015). Oxidative stress-induced apoptosis and matrix loss of chondrocytes is inhibited by eicosapentaenoic acid. Journal of Orthopaedic Research, 33, 359-365.

Smolen, J., \& Steiner, G. (2003). Therapeutic strategies for rheumatoid arthritis. Nature Reviews Drug Discover, 2, 473-488.

Simopoulos, A. (2002). Omega-3 Fatty Acids in Inflammation and Autoimmune Diseases. Journal of the American College of Nutrition, 21(6), 495-505.

Volker, D. H., Fitzgerald, P. E. B., \& Garg, M. L. (2000). The eicosapentaenoic to ocosdahexaenoic acid ratio of diets affects the pathogenesis of arthritis in Lew/SSN rats. Journal of Nutrition, 130(3), 559-565.

Watson, H., Mitra, S., Croden, F. C., Taylor, M., Wood, H. M., Perry, S. L., Spencer, J. A., Quirke, P., Toogood, G. J., Lawton, C. L, Dye, L., Loadman, P. M., \& Hull, M. A. (2018). A randomised trial of the effect of omega-3 polyunsaturated fatty acid supplements on the human intestinal microbiota. Gut, 67(11), 1974-1983. 